\title{
The Relationship between Eating Pattern and Eating Behavior in Preschool Children Aged 4-5 Years at Al-Ikhlas
}

\author{
Haerani $^{1 *}$, Haerati ${ }^{2}$ \\ Departemen of Child and Maternity Nursing, Stikes Panrita Husada Bulukumba, Indonesia1 \\ Departemen Community and Family Nursing, Stikes Panrita Husada Bulukumba ,Indonesia ${ }^{2}$
}

Corresponding Autor : ainunhaerani@yahoo.com*

\begin{abstract}
According to data from the Bulukumba district health office in 2014, there were 44\% malnutrition in preschool children and 2015 there was 53\% malnutrition in preschool children due to irregular children's eating patterns. The data obtained showed that the incidence of preschool children experiencing malnutrition is increasing from year to year. The purpose of this research is to know the relationship between eating patterns and eating behavior in preschool children aged 4-5 years at Al-Ikhlas Kindergarten, Benteng Gantarang Village, Gantarang District, Research Design using Cross-Sectional. The study population was parents who had children aged 4-5 years in Al-Ikhlas Kindergarten which counted 58 people. A sample of 37 people were taken using consecutive sampling techniques using questionnaire and interview instruments. In AL-Ikhlas Kindergarten, Benteng Gantarang Village, Gantarang District, Bulukumba Regency, 58 students were formed consisting of 2 groups A and B, and after interviews of 20 parents, there were found that there were those who easily ate 8 people and had difficulty eating 12 people. Chi-square test results obtained $P=0.004$. This means that there is a significant relationship between eating patterns with eating behavior in preschool children aged 4-5 years at Al-Ikhlas Kindergarten, Benteng Gantarang Village, Gantarang District. It is recommended that parents can provide regular eating patterns to children so that the child's eating behavior becomes good.
\end{abstract}

Keywords: Eating Pattern, Eating Behavior

\section{INTRODUCTION}

Eating behavior is an important thing that needs to be known in depth. Based on theoretical studies, namely to reduce eating behavior problems that arise can vary from choosing to eat certain foods, limiting the amount of food intake, overeating, to the occurrence of food disorders that impact on growth and development disorders (Nafratilawati, 2014). Difficulty eating in children one of the many problems in children that are often encountered in the community. Difficulty eating is identified when a child refuses or is unable to accept a sufficient amount of food or drink variation, while the child needs adequate nutrition to maintain his nutritional status. Difficulty eating in children has adverse effects, both for parents and the child itself. These detrimental effects can include inappropriate weight gain, important nutritional deficiencies, and 
reduction in variations in children's food intake. Difficult eating for a long time can also cause growth failure in children and delays in growth and development in children (Kadarhadi, 2012). The nutritional status of the incidence of problems with eating disorders in some countries is quite high. A study in 2010 in the UK said $20 \%$ of parents reported their children only wanted to eat certain foods. A study in Italy revealed that $6 \%$ of babies experience difficulty eating, then increase by $25-40 \%$ during the final phase of growth. Another survey in the United States said that $19-50 \%$ of parents complained that their children were very picky in eating so that certain nutritional deficiencies occurred (Harinda, 2012).

According to a 2012 census conducted by the World Healt Organization (WHO), $42 \%$ of the 15.7 million child deaths under 5 years occurred in developing countries. From these data also found as many as $84 \%$ of cases of malnutrition in children under 5 years old occur in Asia and Africa (Ministry of Health, 2012) (Rohmasari, 2013). In Indonesia, it was found that the prevalence of insomnia was $33.6 \%, 44.5 \%$ of the study subjects had experienced insomnia for more than 3 months. In the province of East Java in 2010 there were 2.4 million children under five and $15 \%$ of them had problems eating. In Ponogoro Regency in 2010 there were 146 toddlers experiencing difficulty in eating (Ariana, Riri, \& Febriana, 2015). According to data from the Bulukumba district health office in 2014, there were 44\% malnutrition in preschool children and in 2015 there were 53\% malnutrition in preschool children due to irregular children's eating patterns. The data obtained showed that the incidence of preschool children experiencing malnutrition is increasing from year to year. Meanwhile various problems among preschool children (kindergarten) include the lack of optimal growth and one of the determining factors is nutritional factors so that it is necessary to make regular eating habits that are eating 3 times a day on time (Matondang, 2010) .

Means of feeding and education which include the frequency and duration of time (eating patterns) affect the nutritional status of preschool children. The tabulation results show that children who have irregular eating patterns as many as 13 children (76.5\%) will have less nutritional status, while children who have regular eating patterns as many as 32 children (88.9\%) will have normal nutritional status. Nevertheless there are also children who eat regularly as many as 4 children $(11.1 \%)$ have underweight nutritional status. This situation can be caused by the possibility of the child suffering from illness, because if the child is sick the appetite decreases and 
loses weight. Whereas 4 children (23.5\%) have irregular eating patterns but have normal nutritional status. This is because 3 meals usually meet nutritional needs and children are only given snacks / snacks in the form of milk only once (Anita, 2012).

Based on the data obtained at Al-Ikhlas Kindergarten Benteng Gantarang Village, Gantarang District, Bulukumba Regency, the number of students was 58 consisting of 2 groups, group A and group B, and after interviews with 20 parents of students found that there were those who easily ate 8 people and it's hard to eat 12 people. From some of the above data descriptions, the researchers are interested in conducting research with the title "Relationship between Eating Patterns and Eating Behavior in preschool children aged 4-5 years at Kindergarten Al-Ikhlas Benteng Gantarang Village, Gantarang District, Bulukumba Regency .

\section{MATERIAL AND METHODS}

This type of research uses a descriptive-analytic research design that is research that aims to find the relationship between the variables studied using the cross sectional approach which is a study in which the data collection of several research variables is done at one time (Setiadi, 2013). In this study, researchers wanted to know the relationship of eating patterns with eating behavior in preschool children aged 4-5 years at Al-Ikhlas Kindergarten, Benteng Gantarang Village, Gantarang District, Bulukumba Regency. The population in this study are parents who have children aged 4-5 years in Al-Ikhlas Kindergarten Benteng Gantarang Village, Gantarang District, Bulukumba Regency, which counted 58 people. Sampling technique or sampling method is a method determined by researchers to determine or choose the number of samples from the population (Dharma, 2011). The sampling technique used in this study is Consecutive Sampling is a sample selection method that is done by selecting all individuals who meet and meet the selection criteria, until the desired number of samples are met (Dharma, 2011). the number of samples is 37 people.

The research instrument used in this study was an independent variable using an interview sheet. The interview sheet used was to find out the eating patterns of children as many as 37 items in the form of questions if the child ate on time was given a check $\operatorname{mark}(\sqrt{ })$, and if the child did not eat given a sign $(-)$, while the dependent variable using the questionnaire sheet used was to find out the eating behavior in children as many as 19 items in the form of statements using a Likert scale with answer choices always given a score of 4 , often given a score of 3 , sometimes discounted 2 , and never given a score of 
1. Bivariate analysis is an analysis to find out the interaction of two variables, whether in the form of comparative, associative, or correlative (Saryono, 2013). This research was conducted to determine the relationship between variables, the analysis used was a bivariate analysis with the chi-square test if it fulfilled the requirements, namely expected count value $>5$ and if it did not meet the requirements or there were more than 0 cells, an alternative test was used, namely the Fisher test for $2 \times 2$ table with significance level $\mathrm{p}<(\alpha=0.05)$.

\section{RESULTS}

Table 1. Frequency Distribution of Respondents by Age

\begin{tabular}{lcc}
\hline Age & $\mathbf{n}$ & Percentage (\%) \\
\hline 4 Year & 14 & 37,8 \\
5 Year & 23 & 62,2 \\
\hline Amount & 37 & 100 \\
\hline Based on the age characteristics of table & 5.1 obtained from 37 respondents.
\end{tabular}

Characteristics of respondents by age can be seen that the most is the age of 5 years as many as 23 respondents (62.2\%), with the age of 4 years as many as 14 respondents (37.8).

Table 2. Frequency Distribution of Respondents by Gender

\begin{tabular}{llc}
\hline Gender & n & Percentage (\%) \\
\hline Male & 14 & 37,8 \\
Female & 23 & 62,2 \\
\hline Amount & $\mathbf{3 7}$ & $\mathbf{1 0 0}$ \\
\hline
\end{tabular}

Based on the sex characteristics in table 2 obtained from 37 respondents.

Characteristics of respondents by sex can be seen that the most is female gender as many as 23 respondents (62.2) with males 14 (37.8).

Table 3. Frequency Distribution of Respondents by Class

\begin{tabular}{llc}
\hline Class & n & Percentage (\%) \\
\hline A & 26 & 70,3 \\
B & 11 & 29,7 \\
\hline Amount & $\mathbf{3 7}$ & $\mathbf{1 0 0}$ \\
\hline
\end{tabular}

Based on the characteristics of the Class in tabe 13 obtained from 37 respondents.

Characteristics of respondents by Class can be seen that the most is Class A, as many as 26 respondents (70.3) with Class B 11 (29.8).

Table 4. Frequency Distribution of Respondents by Diet

\begin{tabular}{lcc}
\hline Dietary habit & n & Percentage (\%) \\
\hline Reguler & 20 & 54,1 \\
Irreguler & 17 & 45,9 \\
\hline Amount & 37 & 100 \\
\hline
\end{tabular}




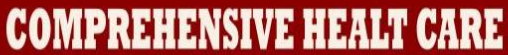

Based on the results of the tabulated data in table 5.4 of 37 respondents in TK ALIkhlas based on the respondents' eating patterns, the results obtained are that respondents who are in the regular eating category that is as many as 20 respondents (54.1\%), with a dietary category that is not regularly 17 respondents (45.9\%).

Table 5. Frequency of Respondents Distribution Based on eating behavior

\begin{tabular}{lcc}
\hline Eating behavior & $\mathbf{n}$ & Percentage (\%) \\
\hline Good & 26 & 70,3 \\
Not Good & 11 & 29,7 \\
\hline Amount & $\mathbf{3 7}$ & $\mathbf{1 0 0}$ \\
\hline
\end{tabular}

Based on the results of the tabulation of data in table 5 of 37 respondents in TK ALIkhlas based on respondents' eating behavior seen that respondents who are in the category of good eating behavior as many as 26 respondents (70.3\%), with a category of less good behavior as many as 11 respondents ( 29.7\%).

Table 6. Frequency Distribution of Relationship between Diet and Eating Behavior

\begin{tabular}{|c|c|c|c|c|c|c|c|}
\hline \multirow{3}{*}{ Dietary habit } & \multicolumn{6}{|c|}{ Eating behavior } & \multirow[t]{3}{*}{ P Value } \\
\hline & \multicolumn{2}{|l|}{ Good } & \multicolumn{2}{|c|}{ Not Good } & \multicolumn{2}{|c|}{ Amount } & \\
\hline & $\mathbf{n}$ & $\%$ & $\mathbf{n}$ & $\%$ & $\mathbf{N}$ & $\%$ & \\
\hline Reguler & 18 & 48,6 & 2 & 5,4 & 20 & 54,1 & \\
\hline Irreguler & 8 & 21,6 & 9 & 24,3 & 17 & 45,9 & 0,004 \\
\hline Amount & 26 & 70,3 & 11 & 29,7 & 37 & 100 & \\
\hline
\end{tabular}

In this Bivariate analysis the results of the cross tabulation are presented between the independent variables namely the diet with regular and irregular indicators and the dependent variable namely eating behavior with good and unfavorable indicators. Based on table 5.6 it can be seen that respondents on regular eating patterns with good eating behavior are 18 people (48.6\%), while eating behavior is not good which is $2(5.4 \%)$. Respondents of irregular eating patterns with good eating behaviors are 8 people (21.6\%) while irregular eating patterns with bad behavior are 9 people (24.3\%). The results of data analysis using the Chi-square test obtained $P=0.004$. From the results of the chi-square test if it is associated with the acceptance criteria of the hypothesis proposed by the chi-square test if it is associated with the acceptance criteria with the acceptance criteria of the proposed hypothesis, it is known that the value of $\mathrm{P}=(0.004)$ $<\alpha=0.05$. This means that the proposed hypothesis is declared accepted. So that there is a relationship between eating patterns with eating behavior.

\section{DISCUSSION}

Based on the results of research in TK AL-Ikhlas based on the eating patterns of respondents, it was found that respondents who were in the category of regular eating patterns were 26 respondents (54.1\%), while in the category of irregular eating 
patterns as many as 17 respondents (45.9\%). This shows that preschoolers generally have a regular eating pattern because because parents pay attention to their child's eating schedule. Unhealthy and unbalanced eating patterns for preschoolers can cause impaired nutritional status, impaired nutritional status in preschoolers or golden age greatly affects their development. Poor patterns cause poor nutritional status, poor nutritional status causes many developmental disorders for preschoolers which cause growth delays and developmental disorders for preschoolers (Lida Khalimatus sa'diya, 2015).

The regular eating patterns of respondents are caused because parents have taught good eating habits to children since childhood. As early as possible taught to children about good eating habits can carry over into adulthood and can affect the quality of life. For preschoolers to follow family eating patterns and their shape and needs must be regulated. Parents tend to regulate their child's diet based on the type and amount of food eaten, but do not pay attention to eating schedule. Respondents who have irregular eating patterns because parents suddenly cultivate eating discipline in children, they tend to obey the wishes of children without regard to the nutritional value that their children eat.

To be able to create a regular diet, the food served must vary. The food provided must be varied or not boring, because variations in food will be able to increase a child's appetite so that the nutritional needs in the body are met.

Food needs need to be regulated so that it is usually accepted by children in one day. By dividing food into three times a day so that nutritional intake needs can be met properly in one day. Research conducted in line with research conducted by Khalimatus Lida, (2015) with the title "The Relationship of Eating Patterns With the Nutritional Status of Preschoolers in Paud Tunas Muliah Claket Pacet Mojokerto District". This research uses correlation analytic design with cross sectional approach. The population of this study were all mothers and preschool children in Precious Tunas Paud totaling 17 people. The sampling technique used in this study is total sampling. Analysis of the data used is the spearman's rho test with a value $(0.038)<\alpha(0.05)$ meaning that there is a relationship between eating patterns and nutritional status of preschool children in PAUD Tunas Mulia Claket Village, Pacet Village, Mojokerto District. The results showed that preschool-aged children have a good diet, namely 11 children (64.7 respondents) 
and normal nutritional status, namely 13 children (76.4\%) who have a good diet, normal nutritional status.

Based on the analysis of researchers eating habits of children who are regularly caused because parents have taught good eating habits to children since childhood. As early as possible taught to children about good eating habits can carry over into adulthood and can affect the quality of life. Parents also pay attention to the child's feeding schedule three times a day, morning at 06.00-08.00, afternoon at 12.00-14.00, and night at 19.00-21.00, while children who eat irregularly because parents do not pay attention to the feeding schedule and their children only want to eat past the meal schedule it should. Based on the research results at AL-Ikhlas Kindergarten, it was found that respondents who were in the category of good eating behavior were 26 respondents (70.3\%), while poor behavior was 11 respondents (29.7\%).

Different eating behaviors in each child can provoke different reactions for mothers in the face of preformance and the results of in-depth interviews found that mothers generally succumb to children's desires. The mother still gives food that the child likes so the child wants to eat. There is also a mother who claims to scold her child a little if the child refuses to eat. The mother also persuades the child so that the child wants to try new foods that he knows. Generally, mothers also no longer provide new types of food that children refuse at the first opportunity. When compared with the results of Carrut's research, 2010. It is known that mothers introduce new types of food 3-5 times before deciding that children don't like them. Previous research conducted by Bari and Sullirvan, 2010 said that repetition of food 8-15 times is important to increase children's acceptance of new types of food, and when mothers stop feeding when the child rejects it on the first opportunity it can actually make children more picky about food.

Based on the results of Iskandar's research, 2010 there are two characteristics of mothers in dealing with children's eating behavior. The expected characteristics of the mother that are flexible are sensitive to the signal the child is showing. Listening and responding to their wishes. Responding to the wishes of the child, does not mean harming all the wishes of the child, but listening to children to reasonable limits and responding appropriately. According to Cathey and Gayload's research results, 2010 parents are strongly discouraged from pursuing a child's total will by only providing the food they like. This can limit a child's food opportunities for other types of food. Unexpected characters are those that are stressful for children. In this character, the 
mother feels that she is the most entitled and most aware of the child's food intake and eating schedule. They have difficulty eating in translating signals given by children. If faced with the wrong child will fail to form good eating habits. Negative experiences, which are obtained by children related to food, will result in food rejection (Holden and Mac Donald, 2010). Instead of improving eating behavior, children will actually experience difficulties with their eating behavior. Another study conducted by Piazza, 2010 found that mothers who faced eating behavior incorrectly (distracting, persuading with excess, providing food and children's favorite toys) actually worsened eating behavior.

The results of this study are in line with research conducted by (Sahyani, 2012), "The Effectiveness of Economic Tokens for Improving Eating Behavior in Children with Difficulties to Eat. This study uses a single-case experimental desing with ABA withdrawal treatment format. The data obtained were then analyzed using visual inspection analysis techniques to see changes and compare the effectiveness of the treatment. The results showed an increase in eating behavior in both subjects. In the first subject, eating behavior increased by $72 \%$, especially in the aspect of wanting to eat alone with a percentage increase of $100 \%$.

Based on the analysis of researchers the number of children with good eating behavior is because children easily eat appetite to eat, do not pick and choose food, like many types of food, like vegetables, like large portions, and spend their food. Poor eating behavior is caused by the child picking out food and the way the mother gives food is not in accordance with the wishes of the child. In this univariate analysis, cross tabulation is presented between the independent variables, namely eating patterns with regular and irregular indicators and the dependent variable, which is eating behavior with good and unfavorable indicators. Based on table 5.5 it can be seen that respondents with regular eating patterns are 26 (70.3\%), irregular eating patterns 11 (29.7\%), and good eating behavior 19 (51.4\%), poor eating behavior $17(45,9 \%)$.

Irregular and unbalanced eating patterns for preschoolers can cause disrupted eating behavior, disrupted eating behavior in preschoolers or golden age greatly affects their development. Bad patterns cause bad eating behavior too. Poor eating behavior causes many disturbances in the frequency of eating for preschoolers. A good eating pattern is caused because parents have taught good eating habits to children since childhood. At this time it may be taught to children about good eating habits that can 


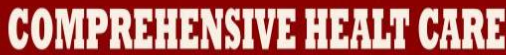

carry over into adulthood and can affect their quality of life. For preschoolers to follow family eating patterns and their shape and needs must be regulated. Parents tend to regulate their child's diet based on the type and amount of food eaten, but do not pay attention to eating schedule.

Poor eating patterns because parents do not cultivate discipline of how to eat in children, they tend to obey the wishes of children without regard to the nutritional value that their children eat, with regular eating patterns that lead to good eating behavior because by regulating the eating patterns of children eating children are able to follow kebiaaan which is often done on him so that the pattern of the child's self to regulate diet. To be able to create a good diet, the food served must vary. Varied food causes children's interest in eating to increase causing good eating behavior of children (Lida Khalimatus sa'diya, 2015). The results of this study are in line with research conducted by (Nafratilawati, 2014). The relationship between parenting and feeding difficulties in preschool children (3-5 years) in Lelayangan Kindergarten, Semarang. This research uses descriptive correlation with cross sectional approach. Using the chi square test. Obtained the results of the p value of 0.006 ( $p$ value $<0.05$ ), it was concluded that there is a relationship between parenting parents with difficulty eating in preschool children (3-5 years) in kindergarten Lelayangan, Semarang Regency.

Based on the analysis of researchers say that, research conducted shows the relationship between eating patterns with eating behavior, this is because children's eating patterns affect eating behavior of many children so parents need to pay more attention to eating patterns that are less good so as not to affect eating behavior in children. But for this child's eating patterns for the better because he saw his parents pay attention to the eating schedule with 3 meals a day ie morning at 06.00-08.00, afternoon at $12.00-14.00$, night $19.00-21.00$, so that daily eating behavior can be maximized for the children.

\section{CONCLUSIONS}

There is a relationship between eating patterns and eating behavior in parents who have preschool children aged 4-5 years in TK AL-Ikhlas Benteng Gantarang Village Bulukumba in 2016, with significance values $p=0.004<\alpha=0.05$. It is expected that parents can provide regular eating patterns to children so that children's eating behavior can be good and is expected to provide information about the importance of eating patterns in regulating children's eating behavior. 


\section{REFERENCES}

Adriani, M., \& Wirjatmadi, B. (2012). Peranan Gizi Dalam Siklus Kehidupan.Jakarta: Prenadamedia Group.

Devi, N. (2012). Gizi Anak Sekolah. Jakarta: Pt.Kompas Media Nusantara.

Dharma, K. K. (2011). Metodologi Penelitian Keperawatan Panduan Melaksanakan Dan Menerapkan Hasil Penelitian. Jakarta: Cv. Trans Info Media.

Fitriani, F., Febry, F., \& Mutahar, R. (2009). Gambaran Penyebab Kesulitan Makan Pada Anak Prasekolah Usia 3-5 Tahun Di Perumahan Top Amin Mulya Jakabaring Palembang.

Harinda, L. (2012). Proporsi Dan Status Gizi Pada Anak Prasekolah Dengan KesulitanMakan Di Semarang . Studi Kasus Di Kelurahan Tandang Dan Sendangguwo , Program Pendidikan Sarjana Kedokteran Fakultas Kedokteran Universitas Diponegoro.

Hariyani, S. (2011). Gizi Untuk Kesehatan Ibu Dan Anak. Yogyakarta: Graha Ilmu.

Hidayat, A. A. (2012). Pengantar IImu Keperawatan Anak. Jakarta: Salemba Medika.

Kadarhadi, E. (2012). Pengaruh Konseling Dengan "Feeding Rules" Terhadap Status Gizi Anak Dengan Kesulitan Makan. Jurnal Medika Muda Karya Tulis Ilmiah, Program Pendidikan Sarjana Kedokteran Fakultas Kedokteran Universitas Diponegoro 2012.

Mohammad, I. (2015). Mencetak Anak Sehat,Cerdas, \& Ceria. Jakarta: Bestari Buana Murni.

Nafratilawati, M. (2014). Hubungan Antara Pola Asuh Dengan Kesulitan Makan Pada Anak Prasekolah (3-5 Tahun) Di Tk Leyangan Kabupaten Semarang. Program Studi IImu Keperawatan Sekolah Tinggi IImu Kesehatan Ngudi Waluyo Ungaran

Novi, B. (2015). Kebiasaan-Kebiasaan Buruk Sehari-Hari Bahayanya Bagi Kesehatan Fisik Dan Mental Anak. Jakarta: Flashbooks.

Nurafriani. (2013). Faktor-Faktor Yang Berhubungan Dengan Kesulitan Makan Pada Anak Usia 3-5 Tahun Di Tk Perwanida Batu-Batu Kabupaten Soppeng. Stikes Nani Hasanuddin Makassar.

Rohmasari, A. (2013). Faktor-Faktor Yang Mempengaruhi Sulit Makan Pada Balita. Program Studi D Iii Kebidanan Fakultas IImu Kesehatan Universitas Muhammadiyah Penorogo.

Sahyani, R. (2012). Efektivitas Token Ekonomi Untuk Meningkatkan Perilaku Makan Pada Anak Yang Mengalami Sulit Makan. Universitas Ahmad Dahlan . 


\section{COMPRAHENSWEHABH CARE}

Saryono. (2011). Metodologi Penelitian Kesehatan. Yogyakarta: Mitra Cendikia.

Setiadi. (2013). Konsep Dan Praktik Penulisan Riset Keperawatan. Yogyakarta: Graha Ilmu.

Sodikin. (2012). Keperawatan Anak Gangguan Pencernaan. Jakarta: EGC.

Soedibyo, S., \& Mulyani, R. L. (2009). Kesulitan Makan Pada Pasien Survei Di Unit Pediatri Di Unit Pediatri Rawat Jalan.

Telaumbanua, L. K. (2013). Faktor-Faktor Yang Mempengaruhi Sulit Makan Pada Usia Prasekolah Di Tk Islam Nurul Hikmah Bantar Gebang Bekasi Tahun 2013. Program Studi D Iii Kebidanan Sekolah Tinggi IImu Kesehatan Medistra Indonesia Bekasi 2013.

Ulfa, M. (2015). Beragam Gangguan Paling Sering Menyerang Anak. Yogyakarta: Flashbooks. 